\title{
PARATHYROID ADENOMA IN A CHILD PRESENTING AS RICKETS
}

\author{
BY \\ B. S. B. WOOD, W. H. GEORGE and A. W. ROBINSON \\ From Dudley Road Hospital, Birmingham
}

(RECEIVED FOR PUBLICATION JULY 4, 1957)

Primary hyperparathyroidism in childhood is rare. Anspach and Clifton found only 12 cases up to 1939 and since then a few cases in children have been reported by Pugh (1946), Tsumori, Jensen, Hunnicutt, Foreman and Kinsell (1955), Crawford, Stefanelli and Alvarez (1956); these have in general, shown the changes typical of the adult.

The case described here is thought worthy of notice, not only in view of the age, but also because the degree of renal involvement and the radiological features were misleading at the time; in addition, as Dent and Hodson (1954) have stated, primary parathyroid disease in childhood may help to elucidate further the mode of action of parathyroid hormone.

\section{Case Report}

John W., aged 12, was first seen in March, 1956, with a five months' history of lethargy, vomiting, anorexia,

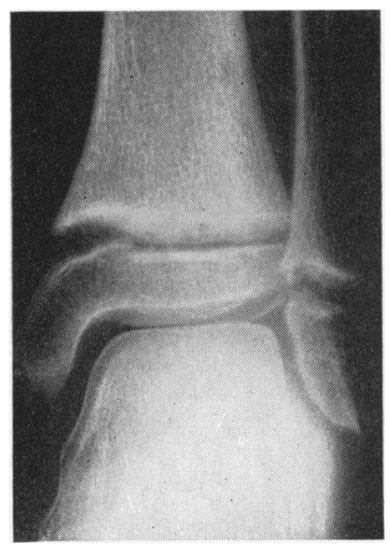

FIGs. 1.-Radiographs showing changes of late rickets. thirst and polyuria, following a fracture to the left radius and ulna. This fracture resulted from a fall while wrestling with another boy and no obvious radiological abnormality was seen in the bone. No definite clinical abnormality was detected at this time. His blood pressure was $100 / 60 \mathrm{~mm}$. Hg and his urine was normal apart from 4 white blood cells per high-power field.

His symptoms continued and a few months later he complained of pain in the left ankle, which on radiographs showed changes of late rickets (Figs. 1 and 2). He was therefore admitted for further study 17 months after the onset of symptoms. The muscles were flabby, the skin slightly pigmented and his blood pressure had risen to $130 / 100 \mathrm{~mm}$. $\mathrm{Hg}$.
Investigations gave the following results:

There was no albumin in the urine, but 4-6 white blood cells per high-power field. The specific gravity after a 12-hour fluid fast was 1010 . Other results were as follows:

\begin{tabular}{|c|c|c|c|}
\hline Blood & March 11, 1957 & March 20, 1957 & April 3, 1957 \\
\hline $\begin{array}{ll}\text { Calcium } & . . \\
\text { Phosphorus } \\
\text { Urea } \quad . \\
\mathrm{CO}_{2} \quad .\end{array}$ & $\begin{array}{l}14 \mathrm{mg} . \% \\
3.8 \mathrm{mg} \% \\
46 \mathrm{mg} . \% \\
40 \text { vol. } \%\end{array}$ & $\begin{array}{l}16 \mathrm{mg} . \% \\
2.1 \mathrm{mg} . \% \\
40 \mathrm{mg} . \% \\
52 \text { vol. } \%\end{array}$ & $\begin{array}{l}17.5 \mathrm{mg} . \% \\
4.7 \mathrm{mg} . \% \\
28 \mathrm{mg} . \% \\
48 \text { vol. } \%\end{array}$ \\
\hline
\end{tabular}

(Soon after admission he developed acute appendicitis; this was treated by appendicectomy and at this time his blood urea rose to $80 \mathrm{mg}$. \% and his alkali reserve fell to 20 vol. \%.)

Excretion pyelography showed poor concentration of the dye but normal calyces were seen.

Urine excretion studies on a low-calcium diet (less than $100 \mathrm{mg}$. calcium per day) gave $0 \cdot 41 \mathrm{~g}$. calcium per day and $1 \cdot 23 \mathrm{~g}$. phosphorus per day.

The calcium content of C.S.F. was $5.5 \mathrm{mg}$. \%. According to $\mathrm{H}$ o w a rd, Carey, Rubin and Levine (1949) a level below $6 \cdot 0$ $\mathrm{mg}$. \% in the presence of hypercalca emia suggests primary hyperparathyroidism.

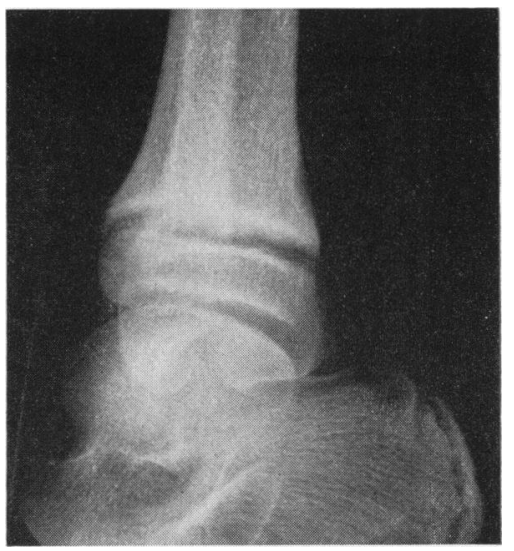

FIG. 2.-Radiographs showing changes of late rickets.
The princi-

pal features radiologically were generalized osteoporosis and subperiosteal erosions, particularly in the phalanges and the upper medial and lower posterior margins of the tibiae (see Fig. 2). The confusing element was the rachitic changes at the lower radial, ulnar, tibial 


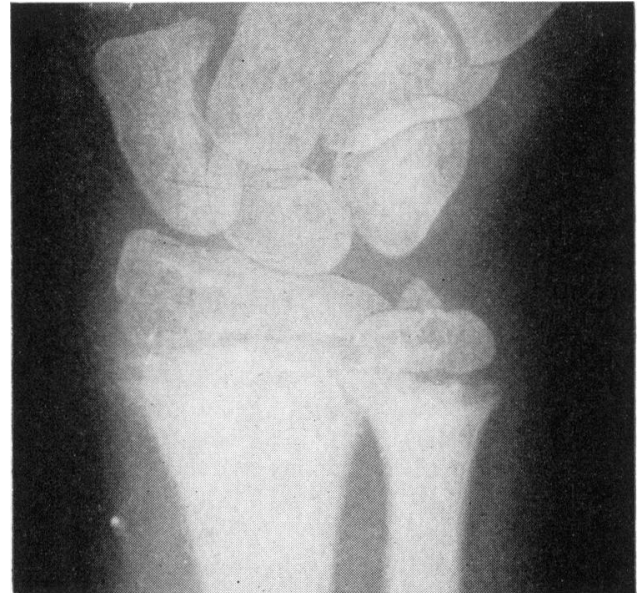

FIG. 3.-Radiographs showing changes of late rickets.

and fibular metaphyses on both sides (see Figs. 1, 2 and 3). A dental radiograph was also taken and showed intact lamina dura (as also did Tsumori and his colleagues' (1955) child of 10 with primary hyperparathyroid disease), a feature pointing against parathyroid hyperactivity of any duration.

The differential diagnosis between primary and secondary hyperparathyroidism has been summarized by Dent and Hodson (1954); this boy's biochemical findings fell neatly into the primary group, while the radiological features were equally typical of secondary or renal osteodystrophy, the impaired kidney function also tending to support the latter diagnosis. It was, however, clear that if a parathyroid tumour were suspected, the neck must be explored.

At operation an oblong tumour, 1 in. by $\frac{3}{4}$ in., was removed from behind the left lower pole of the thyroid, which on histology was found to be an adenoma of the wasserhelle cells (Figs. 4 and 5). Both sides of the neck were explored without any further abnormality being encountered.

The post-operative course was uneventful, the serum calcium level falling to $8.9 \mathrm{mg}$. \% by the end of a week and the urinary calcium on a high calcium intake falling to below $0.05 \mathrm{~g}$. per day.

When last seen two months after operation he was in good health with a blood pressure of $130 / 80 \mathrm{~mm}$. $\mathrm{Hg}$ and normal calcium and phosphorus levels in the serum.

\section{Discussion}

A review of the literature makes it clear that quite severe renal impairment can occur as the result of primary hyperparathyroidism, atypical cases presenting as diabetes insipidus (Albright and Reifenstein, 1948) or hypertension (Race, 1952).

We should not therefore have been much influenced by the failure of this boy's kidneys to concentrate. We were, however, considerably disturbed by the radiological appearances of rickets, as Dent and Hodson (1954) imply that the essential difference between primary hyperparathyroidism and the secondary form due to renal disease is that in the former there is no sign of rachitic change. This is instanced by the 8-year-old boy reported by Pugh (1946) and similar statements are made by Albright and Reifenstein (1948) and Snapper (1949). However, Caffey (1950) states that in pre-adolescent primary hyperparathyroidism 'rachitic-like changes in the metaphyses have been described', presumably referring to the cases of Duken (1928) and Anspach

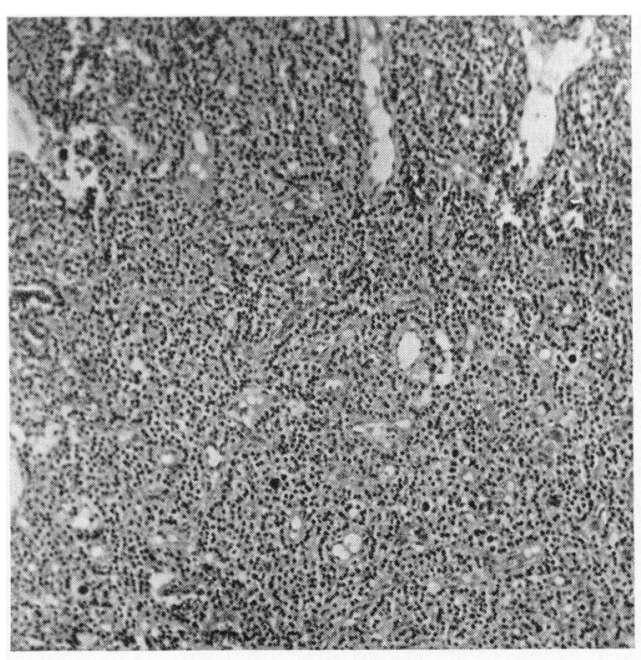

Fig. 4. $-\times 90$.

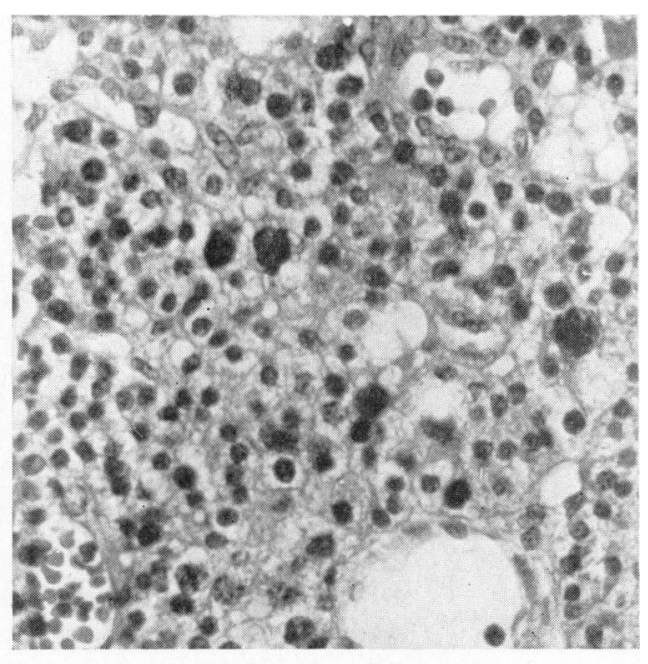

Fig. 5.- $\times 375$. 
and Clifton (1939). Brailsford (1953) too states that in hyperparathyroidism before adolescence the radiographic appearance may be similar to type $B$ renal rickets and he illustrates a case of primary hyperparathyroidism with rachitic changes in the lower ends of the radius and ulna.

Hunter and Turnbull (1931) differentiated the bone histology resulting from primary hyperparathyroidism, in which there is osteoporosis and no increase in osteoid tissue, from that of osteomalacia and rickets where osteoid is increased. They explained that in Schmorl's (1926) cases, where osteomalacia co-existed with hyperparathyroidism, the dietary state in Germany at that time led to the widespread occurrence of both osteomalacia and rickets in the general population. Such is unlikely to be the explanation in our case, as since infancy he regularly imbibed 2 to 3 pints of milk daily and took one teaspoonful of cod-liver oil throughout the winter months. The fact that he developed rickets on such a diet suggests perhaps that the phosphate diuretic effect of the parathyroid hormone predominated over its osteoclastic effect upon the bone. He had been growing 3 in. a year up to the time of his illness and any tendency towards a negative calcium or phosphorus balance might be expected to precipitate a rachitic change at the epiphyses. It does not seem possible to invoke an acidosis as the cause in view of the high serum calcium levels and the normal alkali reserve.

\section{Summary}

A boy of 12 presenting with radiological rickets was found to have the biochemical findings of primary hyperparathyroidism. This was confirmed by removal of a parathyroid adenoma at operation. It appears that radiological rickets can occur in primary hyperparathyroidism without primary renal disease or acidosis.

We are indebted to Dr. A. Booth for permission to reproduce the early radiographs, to Dr. W. H. Caldwell for the histological report on the tumour, to Mr. S. Smith for the biochemical investigations and to Mr. A. J. Higgs for the photomicrographs.

\section{REFERENCES}

Albright, F. and Reifenstein, E. C. (1948). The Parathyroid Glands and Metabolic Bone Disease, p. 59. Baltimore.

Anspach, W. E. and Clifton, W. M. (1939). Amer. J. Dis. Child., $58,540$.

Brailsford, J. F. (1953) The Radiology of Bones and Joints, 5th ed. London.

Caffey, J. (1950). Pediatric $X$-ray Diagnosis, 2nd ed., p. 782. Chicago.

Crawford, D. J. M., Stefanelli, J. and Alvarez, A. F. (1956). Brit. J. Surg., 44, 193 .

Dent, C. E. and Hodson, C. J. (1954). Brit. J. Radiol., 27, 605.

Duken, J. (1928). Z. Kinderheilk., 46, 114.

Howard, J. E., Carey, R. A., Rubin, P. S. and Levine, M. D. (1949). Trans. Ass. Amer. Phys., 62, 264.

Hunter, D. and Turnbull, H. M. (1931). Brit. J. Surg., 19, 203.

Pugh, R. J. (1946). Proc. roy. Soc. Med., 39, 694.

Race, G. J. (1952). N.C. med. J., 13, 659 .

Schmorl, G. (1926). Klin. Wschr., 5, 496.

Snapper, I. (1949). Medical Clinics on Bone Diseases, 2nd ed., p. 104 New York.

Tsumori, H., Jensen, E., Hunnicutt, A., Foreman, N. and Kinsell, L. W.' (1955). J.' clin. Endocr., 15, 1141. 